Analisis penyelesaian konflik agraria dengan pendekatan ekologis antara Masyarakat dengan PTPN V Sei Pagar di Desa Hangtuah Kecamatan Perhentian Raja Kabupaten Kampar

\author{
Laura Dameshita Silalahi ${ }^{1}$, Zulfan Saam ${ }^{2}$, Yusni Ikhwan Siregar ${ }^{3}$ \\ ${ }^{1}$ Mahasiswa Program Studi Ilmu Lingkungan Program Pascasarjana \\ ${ }^{2,3}$ Dosen Program Studi Ilmu Lingkungan Program Pascasarjana Universitas Riau \\ *Correspondentemail: lauradameshita@gmail.com
}

Diterima: 15 Juni 2021| Disetujui: 30 Oktober 2021 | Diterbitkan: 31 Oktober 2021

\begin{abstract}
Agrarian conflicts are the result of development policies in the plantation sector. The community claims the land already planted with oil palm by the company. This research is a qualitative research using primary and secondary data. Primary data obtained from interviews with local government officials, companies and community leaders who were selected purposively at the research location. Secondary data were obtained from village offices, BPS, books, research journals related to agrarian conflicts in the plantation sector. The data collection technique used the triangulation method to obtain valid data. Furthermore, the data were analyzed descriptively. The conflict analysis method used in this study uses a problem tree so that the root of the problem and the causes and consequences of the conflict between the community and the company can be explored. The roots of the problem include the non-fulfillment of the KKPA land and a lack of understanding of land rights. This is caused by a lack of communication between the company and the community, resulting in conflicts. Efforts to resolve conflicts between companies and communities need to be carried out, especially by using an ecological approach.
\end{abstract}

Keywords: Agrarian Conflict; Conflict Resolution; Ecological Approach

Konflik agraria di Indonesia berakar pada tidak adanya kepastian tanah, SDA dan wilayah kelola masyarakat petani, adat dan lokal. Dualisme hukum negara dan hukum adat tidak mendapat koreksi mendasar. Peraturan perundang-undangan mengenai pertanahan, kehutanan, sumber daya alam lainnya tumpang tindih dan bertentangan antara satu dengan yang lainnya. Hal ini dilatar belakangi oleh ekspansi badan-badan usaha raksasa dalam industri ekstraktif, produksi perkebunan dan kehutanan, serta konservasi dalam penguasaan tanah skala luas dengan mengabaikan hukum-hukum adat yang sudah lama berlaku di kalangan rakyat.

Konflik yang berkepanjangan juga melahirkan konflik-konflik baru seperti konflik-konflik etnis, konflik agama, konflik-konflik antar kampung/desa, dan konflik-konflik antar penduduk asli dan pendatang. Konflik agraria yang berlarut-larut menggerus kepercayaan masyarakat terhadap pemerintah karena hubungan masyarakat dengan pemerintah pada dasarnya adalah hubungan saling mengakui satu sama lain (mutual recognition). Jika masyarakat tidak mendapatkan pengakuan akan haknya untuk mempunyai hak atas tanah dari pemerintah maka otoritas pemerintah atas masyarakat akan memudar bahkan hilang sama sekali. Ketika itulah masyarakat akan pergi mencari tempat atau institusi yang mengakui hak mereka untuk mempunyai hak atas tanah. Pengakuan itu justru didapat dari organisasiorganisasi masyarakat sipil, seperti Wahana Lingkungan Hidup Indonesia (Walhi), maupun Konsorsium Pembaruan Agraria (KPA).

Konflik agraria antara perusahaan dan masyarakat banyak terjadi di Provinsi Riau. Munculnya konflik cenderung disebabkan oleh kebijakan pembangunan yang dominan berorientasi ekonomi, baik itu pembangunan fasilitas pemerintahan, proyek strategis nasional, proyek konsumtif, maupun pengembangan perkebunan. Dalam proses ambil alih tanah dari petani, perusahaan membuat perjanjian dengan isi hak dan kewajiban kepada petani pemilik tanah. Selanjutnya perusahaan melakukan pengelolaan lahan perkebunan dan menghasilkan keuntungan, Namun, seiring berjalannya waktu, perusahaan tidak melaksanakan kewajiban. Dari sini muncul gejolak masyarakat sebagai awal konflik.

Berdasarkan laporan KPA 2019 bahwa sepanjang 2019 terjadi 279 kasus konflik agraria di berbagai wilayah di Indonesia dengan total luas wilayah konflik mencapai 734 ribu Ha dan masyarakat terdampak mencapai sekitas 109 ribu kepala keluarga. Angka ini mengalami penurunan jumlah konflik dibandingkan tahun 2018 yaitu 410 konflik namun mengalami peningkatan jumlah luasan wilayah yang terdampak konflik dan jumlah keluarga yang terdampak.

Data Badan Pusat Statistik Provinsi Riau 2019 menyebutkan bahwa perkebunan sawit di Provinsi Riau memiliki luas 2.537.375 Ha dengan luas tertinggi berada di Kabupaten Rokan Hulu yakni 480.665 
Ha, kedua di Kabupaten Kampar seluas 418.236 Ha dan ketiga di Kabupaten Siak seluas 317.552 Ha. Riau menempati posisi peringkat terluas perkebunan sawit di Indonesia dari total luas perkebunan sawit di Indonesia mencapai 14,32 juta Ha. Selain peringkat wilayah terluas, Riau juga menjadi wilayah yang paling tinggi konflik agraria. Ekspansi perusahaan perkebunan kelapa sawit dan hutan tanaman industri (HTI) menjadi penyebab utama konflik agraria tersebut, dimana keputusan pejabat publik yang memberikan izin-izin konsesi kepada perusahaan atas lahan-lahan yang telah dikuasai dan digarap oleh masyarakat.

Kabupaten Kampar merupakan kabupaten dengan luas perkebunan kelapa sawit kedua di Provinsi Riau setelah Kabupaten Rokan Hulu, akan tetapi konflik yang ada di Kabupaten Kampar lebih banyak dibandingkan konflik yang ada di Kabupaten Rokan Hulu. Kabupaten Kampar juga menjadi salah satu Kabupaten dengan jumlah konflik yang paling banyak dan belum terselesaikan. Berdasarkan keterangan dari Kepala Seksi Penanganan Masalah dan Pengendalian Pertanahan Kantor Badan Pertanahan Nasional Kabupaten Kampar terdapat 217 kasus pertanahan yang sudah terdaftar atau tercatat di Kantor Badan Pertanahan Nasional Kabupaten Kampar. Dari 217 kasus pertanahan yang ada, 167 kasus tergolong sengketa dan konflik pertanahan dan 50 kasus tergolong perkara pertanahan yang sudah beracara di pengadilan. Berdasarkan catatan dari Kantor Badan Pertanahan Nasional Kabupaten Kampar, terdapat 45 kasus pertanahan yang sampai saat ini belum selesai ditangani, 31 kasus tergolong perkara pertanahan dimana kasus ini ditangani di lembaga pengadilan dan 14 kasus lainnya tergolong dalam sengketa dan konflik.

Konflik agraria antara masyarakat dengan PTPN V adalah salah satu dari konflik yang waktunya telah lama berlangsung dan belum kunjung selesai. Sejak 1999 masyarakat sudah menuntut hak atas lahannya kepada PTPN V. Masyarakat membentuk kelompok dengan nama Gerakan Masyarakat Pantai Raja untuk berusaha mengkonfrontasi perusahaan lewat berbagai aksi, termasuk aksi mendirikan tenda selama 20 hari di lahan perkebunan sawit dengan tujuan memberi tekanan kepada perusahaan agar segera memenuhi janji sebagaimana kesepakatan bersama. Kesepakatan tersebut yakni menyediakan lahan 150 ha kepada masyarakat dalam bentuk program KKPA. Tuntutan masyarakat hak atas kepemilikan lahan tersebut merupakan adalah akar masalah konflik. Konflik tidak terselesaikan karena pihak-pihak yang berupaya menyelesaikan tidak pernah berangkat dari upaya menyelesaikan akar masalah konflik. Gesekan antara masyarakat dengan PTPN V akan menimbulkan persoalan pada sektor lingkungan, ekonomi dan situasi sosial masyarakat.

\section{Konflik agraria}

Konflik agraria adalah situasi proses interaksi antara dua atau lebih orang atau kelompok yang masing-masing memperjuangkan kepentingan atas objek yang sama yaitu tanah dan benda-benda lain yang berkaitan dengan tanah seperti tanah, air dan juga udara yang berada di atas tanah yang bersangkutan. Pada tahapan saling berlomba untuk memblokir jalan lawan, terjadilah konflik. Menurut Mitchell, et al (2000) dan Hendricks (2004) konflik merupakan sesuatu yang tak terelakkan yang dapat bersifat positif dan negatif. Aspek positif muncul ketika konflik membantu mengidetifikasi proses pengelolaan sumberdaya dan lingkungan tidak berjalan secara efektif, mempertajam gagasan atau informasi yang tidak jelas dan menjelaskan kesalahpahaman. Sementara aspek negative mengakibatkan trauma psikis bagi pihak-pihak yang berkonflik sehingga berpotensi menjadi masalah yang berkepanjangan apabila tidak mencapai sepakat.

\section{Manajemen Konflik}

Menurut Ross (1993). Manajemen konflik merupakan langkah-langkah yang diambil para pelaku atau pihak ketiga dalam rangka mengarahkan perselisihan ke arah hasil tertentu yang mungkin atau tidak mungkin menghasilkan suatu akhir berupa penyelesaian konflik dan mungkin atau tidak mungkin menghasilkan ketenangan, hal positif, kreatif, bermufakat, atau agresif. Manajemen konflik dapat melibatkan bantuan diri sendiri, kerjasama dalam memecahkan masalah (dengan atau tanpa bantuan pihak ketiga) atau pengambilan keputusan oleh pihak ketiga. Suatu pendekatan yang berorientasi pada proses manajemen konflik menunjuk pada pola komunikasi (termasuk perilaku) para pelaku dan bagaimana mereka mempengaruhi kepentingan dan penafsiran terhadap konflik.

\section{Perkebunan}

Perkebunan menurut Nurhajarini (2009:3) diusahakan oleh pemerintah ataupun swasta. Ciri-ciri perkebunan diantaranya modal besar, teknik pengolahannya modern, hasil untuk keperluan ekspor, administrasinya tertib dan teratur, memperhitungkan untung dan atau rugi. Fungsi perkebunan mencakup tiga hal, pertama, fungsi secara ekonomi yaitu peningkatan kemakmuran dan kesejahteraan rakyat serta penguatan struktur ekonomi wilayah dan nasional. Kedua, fungsi ekologi yaitu peningkatan konservasi tanah dan air, penyerap karbon, penyedia oksigen dan penyangga kawasan lindung. Ketiga, fungsi sosial budidaya yaitu sebagai pemersatu kesatuan bangsa. 


\section{METODE PENELITIAN}

Penelitian dilakukan di Desa Hangtuah Kecamatan Perhentian Raja Kabupaten Kampar. Waktu penelitian pada Bulan Agustus 2020 sampai Oktober 2020. Pendekatan penelitian ini adalah kualitatif. Pengambilan sampel data dilakukan secara purposive, (Moleong, LJ. 2005). Teknik pengumpulan dengan triangulasi (gabungan), analisis data bersifat kualitatif dan hasil penelitian lebih menekankan makna daripada generalisasi. Penelitian ini menggunakan dua jenis data yaitu data primer dan data sekunder. Teknik pengumpulan data yang digunakan dalam penelitian kualitatif adalah dengan menggunakan teknik pengamatan (observasi), wawancara, dokumentasi dan catatan lapangan. Analisis data kualitatif dilakukan sejak sebelum memasuki lapangan, selama di lapangan, dan setelah selesai di lapangan. Dalam penelitian ini metode analisa data menggunakan pohon masalah. Manfaat analisa pohon masalah diantaranya:

1. Merumuskan persoalan utama atau masalah prioritas organisasi.

2. Menganalisis secara rinci dalam mengeksplorasi penyebab munculnya persoalan dengan menggunakan metode five whys. Metode five whys adalah suatu metode menggali penyebab persoalan dengan cara bertanya "mengapa" sampai lima level atau tingkat.

3. Menganalisis pengaruh persoalan utama terhadap kinerja/hasil/dampak bagi organisasi atau stakeholder lainnya.

4. Mengilustrasikan hubungan antara masalah utama, penyebab masalah, dan dampak dari masalah utama dalam suatu gambar atau grafik.

5. Mencari solusi atas persoalan utama yang ada.

\section{HASIL DAN PEMBAHASAN}

\section{Kondisi Geografi PTPN V Kebun Sei Pagar}

PTPN V Kebun Sei Pagar terletak pada posisi $0^{\circ} 12^{\prime}-0^{\circ} 20^{\prime}$ Lintang Utara dan $101^{\circ} 14^{\prime}-101^{\circ} 24^{\prime}$ Bujur Timur. Topografi datar-berombak dengan ketinggian dari muka laut antara 7-50 meter, dilalui oleh Sub DAS 2 sungai besar yaitu Sungai Kampar Kanan dan Sungai Kampar Kiri. Iklim PTPN V Kebun Sei Pagar cocok untuk kelapa sawit dengan curah hujan tahunan rata-rata $2472 \mathrm{~mm} /$ tahun, hari hujan 138 , suhu udara rata-rata 26,30 C, dan kelembaban udara nisbi 83\% (PTPN V, 1992). Dalam kurun waktu pembukaan dan penggunaan lahan hingga saat ini, terjadi sedikit perubahan iklim dengan rata-rata curah hujan $2640 \mathrm{~mm} /$ tahun, hari hujan 144, suhu udara $270 \mathrm{C}$ dan kelembaban udara nisbi $75 \%$. Kondisi iklim ini masih mendukung untuk pertumbuhan kelapa sawit.

\section{Pola Ekspansi PTPN V Kebun Sei Pagar}

Berdasarkan Surat Keputusan Menteri Pertanian No. 668/KPTS/KB.510/10/1985 tentang petunjuk umum pelaksanaan proyek Perkebunan Inti Rakyat, kelapa sawit plasma dikembangkan melalui pola PIR-Trans seluas 6000 hektar. Pembangunan kebun, infrastruktur penunjang dan pemeliharaan tanaman sampai umur tanaman produktif dilakukan oleh PTPN V. Kebun dikelompokkan ke dalam 5 Afdeling yaitu Afdeling I seluas 1092 ha, Afdeling II 1500 ha, Afdeling III seluas 1239 ha, Afdeling IV seluas 1026 ha dan Afdeling V seluas 1143 ha. Dengan pembagian kebun kelapa seluas 2 ha/kepala keluarga, didatangkan sebanyak 3000 kepala keluarga petani transmigrasi dari luar daerah (Jawa Tengah, Jawa Barat, Yogya, Jawa Timur) dan transmigran lokal dengan proporsi 60:40. Selain kebun kelapa sawit, setiap kepala keluarga memperoleh lahan pekarangan disatukan dengan lahan pangan masing-masing seluas 0,5 ha. Saat ini lahan pangan sebagian besar sudah ditanami dengan kelapa sawit karena tingginya resiko kegagalan pada pengelolaan tanaman pangan karena serangan hama/penyakit, tata air yang susah dikendalikan serta pemasaran produksi tanaman pangan yang tidak stabil. Lahan pekarangan juga ditanami kelapa sawit sehingga setiap kepala keluarga memiliki hampir 2,5 ha kebun kelapa sawit.

Di masing-masing afdeling kebun plasma dibangun fasilitas umum (fasilitas sosial dan ekonomi) seperti Sekolah Dasar (SD), Koperasi Unit Desa (KUD), Sekolah Lanjutan Tingkat Pertama (SLTP), Puskesmas Pembantu, tempat peribadatan, kantor desa dan pasar desa. Semua fasilitas umum tersebut tersedia di masing-masing desa kecuali Sekolah Lanjutan Tingkat Pertama hanya terdapat di Desa Hangtuah dan Desa Mayang Pongke, sedangkan Puskesmas Pembantu terdapat di Desa Sialang Kubang dan Mayang Pongke. Dengan fasilitas yang ada tersebut, aktivitas masyarakat bisa berjalan dengan baik antara lain pendidikan, kesehatan, penyediaan kebutuhan keluarga sehari-hari, penyediaan sarana produksi usaha tani kelapa sawit dan pemasaran produksi TBS.

Khusus kegiatan di bidang perkebunan, Koperasi Unit Desa memegang peranan yang penting baik sebagai penyedia sarana produksi, penghubung antara Perusahaan Inti dengan petani untuk bimbingan teknis ke petani dalam pengelolaan kebun kelapa sawit dan pemasaran TBS. Mengingat beragamnya kondisi masyarakat maka petani membentuk organisasi kelompok tani berdasarkan kelompok hamparan 
kebun kelapa sawit. Kelompok tani ini merupakan kepanjangan tangan dari KUD dalam mengelola kebun kelapa sawit petani karena bimbingan teknis dari perusahaan inti ataupun pihak lainnya terutama instansi terkait disampaikan melalui kelompok tani. Jumlah kelompok tani berbeda-beda pada masing-masing desa dimana untuk Desa Hangtuah jumlahnya 35 kelompok, Desa Sialang Kubang sebanyak 33 kelompok, Desa Sei Simpang Dua sebanyak 28 kelompok dan Desa Mayang Pongke sebanyak 27 kelompok tani.

Tabel 1. KUD dan Kelompok Tani Di Kebun Sei Pagar, 2020

\begin{tabular}{llll}
\hline No & Desa & Nama KUD & Jumlah Kelompok Tani \\
\hline 1 & Hangtuah & Karya Manunggal & 35 \\
2 & Sialang Kubang & Kusuma Bakti & 33 \\
3 & Sei Simpang Dua & Rukun Makmur & 28 \\
4 & Mayang Pongke & Tri Manunggal & 27 \\
\hline
\end{tabular}

Sumber : Hasil Penelitian, 2020

Lahan merupakan modal utama dalam membangun perkebunan kelapa sawit dan tidak lepas dari dampak pengelolaan oleh petani. Berdasarkan Peta Citra Landsat, diketahui penggunaan lahan di PTPN V Kebun Sei Pagar adalah semak belukar, hutan sekunder, kebun campuran, karet, kelapa sawit, ladang, pabrik kelapa sawit (PKS) dan pemukiman serta fasilitas umum. Animo masyarakat cukup tinggi dimana seluas 646 ha kebun kelapa sawit dikembangkan oleh masyarakat dengan modal swadaya. Kondisi perkebunan yang dikembangkan dengan modal swadaya masyarakat kurang baik pertumbuhan dan produksinya karena pengelolaannya kurang baik, dengan sarana produksi benih seadanya, pemupukan tidak teratur, tata air jelek dan TBS dipanen lebih awal.

\section{Perubahan Keanekaragaman Hayati}

Konversi penggunaan lahan dari hutan sekunder manjadi kebun kelapa sawit berakibat pada perubahan keanekaragaman hayati flora dan fauna. Struktur, keanekaan dan komposisi flora di perkebunan kelapa sawit merupakan vegetasi monokultur yang didominasi oleh kelapa sawit, tetapi masih terdapat tumbuhan lainnya yang tumbuh secara liar di sela-sela barisan kelapa sawit. Penelitian yang dilakukan tahun 1992, menunjukkan adanya 22 jenis tumbuhan liar di sela barisan kelapa sawit, di antaranya yang dominan adalah Akar pakis (Stenochlaena palusteris), Paitan (Axonopus compressus) dan Bambuan 100 (Brachiaria sp.). Selain itu, terdapat juga jenis yang sub dominan seperti Pakis rasam (Gleichenia linearis), Mikania (Mikania cordata) dan kacangan (Pueraria javanica). Diketemukan juga tumbuhan liar yang tumbuh pada batang pohon kelapa sawit yaitu Paku (Neprolepisbisserata) dan Kadaka (Asplenium nidus) dan anakan kelapa sawit yang jatuh karena TBS umur tua atau rontok saat panen dilakukan (PTPN V, 1992).

Fauna juga mengalami perubahan akibat penggunaan lahan untuk perkebunan kelapa sawit. Hasil pengamatan Bagian Bina Lingkungan PTPN V (1992) diketahui bahwa fauna yang hampir mengalami kepunahan adalah jenis Rusa (Cervus unicolor), Kijang (Muntiacus muntjak), Gajah (Elephas Maximus), Bebe (Helarotus malayanus) dan Harimau Sumatera. Sampai tahun 1992, fauna yang berkembang dan mendominasi di areal kebun kelapa sawit adalah Kelas Mammalia, Reptilia, Amphibia, Pisces dan Aves. Kelas Mammalia didominasi oleh 3 jenis yaitu Kondit (Sus acrofa), Lasun (Melogale cinerea) dan Tikus (Ratus sp.). Kelas Reptelia didominasi oleh 7 jenis yaitu Ular Sanca (Phyton sp.), Ular Sendok (Naja sputatrik), Ular Hijau (Dryophis sp.), Kadal (Mabuia multifasciata), Hap-hap (Draco volans), Acrochordus granulatus dan Biawak (Varanus salvator). Dari Kelas Amphibia didominasi oleh 3 jenis yaitu Katak Kecil (Rana sp.), Katak Pohon (Poly pedatus lencomystak) dan Kodok (Bufo melanostictus). Di perairan areal kebun sawit (sungai-sungai kecil) hidup dan berkembang ikan Gabus, Lele, Tawes, Takang, Pantan, Sepat, Barau dan Puyuh. Klas Aves didominasi oleh jenis Balam (Streptopelia chinensis), Jalak (Acridotheres javanicus), Kerucuk (Phyinonotus goiavier) Kacer (Capsychus saularis), Sesep madu, Elang, Cucuk udang, Ayam hutan dan Alap-alap. Sedangkan fauna yang berkembang di pekarangan jenisnya tidak sebanyak di kebun kelapa sawit, hanya terdapat Mammalia, Amphibia dan Aves. Mammalia yang hidup adalah jenis Tikus (Ratus $s p$.), Amphibia dari jenis Katak Kecil (Rana $s p$ ) dan Kodok (Bufo melanostictus). Kelas Aves didominasi oleh burung jenis Burung Gereja (Passer montanus), Burung Pipit (Lonchura mallaca) dan Burung Perinjak (Prinia familiasis). Dalam usaha meningkatkan produksi kelapa sawit, tahun 1985 diintroduksikan fauna serangga penyerbuk kelapa sawit (SPKS) jenis Elaedobius cameronicus dan serangga peredator ulat api jenis Eucanthecona sp.. Selain itu, flora yang diintroduksikan ke areal perkebunan adalah jamur jenis Cordyceps sp. yang menyerang cocon ulat api sebagai salah satu hama utama perusak daun kelapa sawit.

\section{Kondisi Ekonomi Masyarakat}

Kehadiran perkebunan kelapa sawit sangat mempengaruhi peningkatan pendapatan petani plasma, termasuk peningkatan pendapatan masyarakat di sekitar kebun. Ini merupakan salah satu faktor yang berkontribusi terhadap perubahan persepsi masyarakat dalam menerima kehadiran kebun sawit. Terdapat 
peningkatan pendapatan petani plasma dan masyarakat sekitar kebun sawit, demikian pula munculnya usaha-usaha perekonomian baru seperti jasa transportasi (ojek), servise motor, pasar desa dan lain-lain.

Dengan berjalannya waktu, pertumbuhan pendapatan petani plasma dan masyarakat sekitar kebun lebih tinggi dibandingkan dengan pertumbuhan pendapatan per kapita level Provinsi Riau. Hal ini berkaitan dengan laju peningkatan produktivitas kelapa sawit yang menopang peningkatan pendapatan masyarakat di sekitar kebun.

Sejalan dengan kondisi ekonomi, kondisi sosial masyarakat di sekitar perkebunan kelapa sawit juga semakin membaik. Hal ini terlihat dari pendapat masyarakat terhadap kehadiran perkebunan kelapa sawit. Adanya perbaikan infrastruktur, kesempatan kerja, pengendalian konflik menyebabkan perbaikan dalam persepsi masyarakat terhadap perkebunan kelapa sawit. Sementara frekuensi konflik masih tetap ada yang bersumber dari ketidaktahuan masyarakat terhadap batas-batas areal perkebunan kelapa sawit, kurangnya kesadaran dan pemahaman hukum masyarakat dan kecemburuan terhadap pendapatan pengelola perkebunan.

\section{Konflik Agraria PTPN V Kebun Sei Pagar dengan Masyarakat}

Pembangunan perkebunan pada PTPN V Kebun Sei Pagar telah dilakukan dengan legalitas SK Menteri Kehutanan No. 103/Kpts-I/89 tanggal 20 Februari 1989 tentang pelepasan kawasan hutan seluas 21.994 Ha di Sei Pagar Kelompok Hutan Sungai Kampar Kanan Sungai Kampar Kiri di wilayah Kecamatan Siak Hulu dan Kampar Kiri Kabupaten Dati II Kampar Provinsi Riau Dati I Riau untuk perkebunan PT. Perkebunan V dan Hak Guna Usaha No. 152 tanggal 4 Maret tahun 2001 seluas 2.858,84 Ha.

Masyarakat Desa Pantai Raja Kecamatan Perhentian Raja Kabupaten Kampar mengklaim sebagian lahan PIR yang dibangun untuk petani plasma oleh PTPN V seluas 1.030 Ha merupakan areal mereka. Untuk melegalkan upaya hukum masyarakat menamakan diri dengan nama Gerakan Masyarakat Desa Pantai Raja (GEMPAR).

Langkah masyarakat diantaranya menyurati Pemerintah Pusat namun hasilnya bahwa program PIR tidak menyediakan ganti rugi berdasarkan Surat Direktur Jendral Perkebunan No. 941/E/5/1982 dan Surat Menteri Dalam Negeri No. 188.32/4568/Agr tanggal 3 September 1986. Lnagkah tersebut tidak berhenti, masyarakat menyurati Komnas HAM yang menindaklanjuti dengan memfasilitasi adanya mediasi antara PTPN V dan Masyarakat. Hasilnya adalah pengajuan lahan untuk program KKPA kepada Masyarakat Desa Pantai Raja. Kemudian ditindaklanjuti dengan pencarian lokasi. Ciri kebun KKPA diantaranya calon kebun dibeli dengan legalitas yang sah, calon kebun layak secara teknis, calon kebun dapat sesuai dengan hasil produksi sehingga bermanfaat ekonomis. Dari 8 lokasi yang disurvei oleh PTPN $\mathrm{V}$ dan masyarakat, terdapat satu lokasi yang sesuai untuk program KKPA. Kebun tersebut berada di luar Kabupaten Kampar. Namun dalam proses penyiapan berkas administasi untuk pengajuan ke tingkat direksi PTPN V, masyarakat melakukan aksi unjuk rasa dengan mendirikan tenda dan beberapa kali memblokir akses opserasional di Kebun Inti Perusahaan selama 20 hari. Hal ini merupakan langkah masyarakat untuk menekan perusahaan agar mempercepat proses pemberian lahan KKPA kepada 157 KK Masyarakat Desa Pantai Raja yang menuntut lahan kepada PTPN V.

\section{Pohon Konflik Perkebunan Sawit}

Ada dua permasalahan utama dalam konflik agraria antara PTPN V dengan Masyarakat Desa Pantai Raja yakni kurangnya pemahaman pengembalian hak dan belum terpenuhinya lahan KKPA sebagaimana kesepakatan antara kedua belah pihak yang difasilitasi oleh Komnas HAM. Apabila tidak ditangani dengan tepat sangat mungkin akan memunculkan konflik lanjutan, baik antara masyarakat dengan pihak perusahaan maupun di antara sesama warga masyarakat itu sendiri.

Dikaitkan dengan konteks hubungan masyarakat dengan perusahaan ada enam permasalahan utama yang dapat diidentifikasi sebagai potensi/sumber konflik, meliputi alih kelola lahan, pemahaman ganti rugi dan pengembalian hak yang berdampak pada keterbatasan lahan usaha, pengangguran, dan sengketa lahan serta posisi tawar marsyarakat pada program kemitraan, rekrutmen sumber daya manusia dan keterlibatan perusahaan diwilayah sekitar, berdampak pada opportunity cost dan pendapatan rendah, masyarakat tidak merasakan manfaat, sikap negatif terhadap perusahaan. 


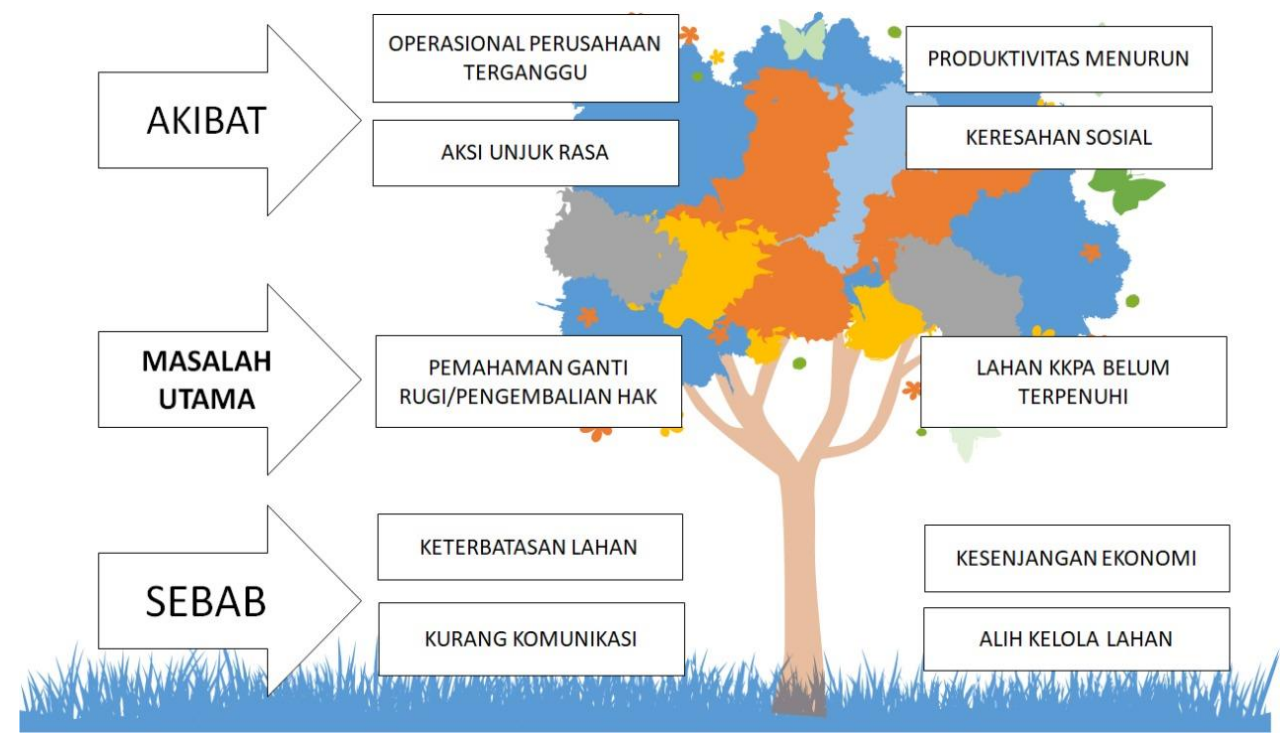

Gambar 1. Pohon Konflik Perkebunan Sawit

Konflik masyarakat dengan perusahaan tentang pengembalian lahan garapan, ganti rugi lahan garapan, ganti rugi pembelian tanah, ketiadaan ijin dari pihak-pihak yang berwenang pada sawit rakyat dan kemudahan dalam inti plasma. Alternatif solusi berupa penguatan posisi tawar petani, advokasi hak dan kewajiban atas pemanfaatan lahan kelompok masyarakat oleh perusahaan, penguatan kapasitas organisasi petani, dan pengembangan trust dan kelembagaan koperasi.

Konflik masyarakat dengan perusahaan tentang pengembalian lahan garapan, ganti rugi pembelian lahan karena kesenjangan. Alternatif solusi berupa pemberdayaan masyarakat, advokasi hak, dan kewajiban atas pemanfaatan lahan masyarakat oleh perusahaan, forum komunikasi yang egaliter di antara stakeholder, pengembangan kelembagaan usaha ekonomi, peningkatan keterampilan untuk kerwirausaha/usaha mandiri.

\section{Strategi Penyelesaian Konflik Masyarakat dengan PTPN V Sei Pagar dengan Pendekatan Ekologis}

Model alternatif pendekatan penyelesaian konflik sebaiknya mengacu pada delapan butir penilaian dengan karakteristik standar, yaitu untuk hasil, berorientasi win-win, hubungan baik, dan kolaborasi; keterlibatan para pihak, berorientasi sukarela, dan partisipatif; gaya interaksi, berorientasi melibatkan pihak terkait; prosedur, berorientasi pada aturan main yang disesuaikan dengan kasus/penyadaran/pemberdayaan; metode, mengajak pihak terkait berorientasi partisipatif dan dialogis, peran penengah, berorientasi beragam pihak penengah; biaya, berorientasi jangka pendek tinggi, jangka panjang rendah; perwakilan, beorientasi adhock, khusus untuk setiap negosiasi.

Model penyelesaian konflik dengan pendekatan ekologis di perkebunan sawit dengan menguatkan peningkatan visi melakukan perencanaan yang apresiatif Lokakarya yang menghasilkan kesepakatan berupa strategi kolektif kemitraan swasta-komunitas usaha bersama, kebun kemitraan, dan koperasi implementasi inovasi hasil konsorsium penelitian dan pengembangan petani.

Penguatan penyelesaian konflik dengan memanfaatkan dialog-dialog kebijakan temuan publik, proses penyadaran diantara para pihak yang berkonflik melalui pihak yang netral dengan tujuan penyelesaian yang dinegosisiakan diantaranya peraturan, kejelasan status kepemilikan asset, pilihan cara penyelesaian melalui peradilan, musyawarah, jalur politik, kolaborasi dan konpensasi.

\section{KESIMPULAN}

Ekspansi perkebunan kelapa sawit mengakibatkan perubahan lingkungan, ekonomi dan sosial masyarakat. Perubahan lingkungan pada menurunnya keragaman hayati. Secara ekonomi, keberadaan perkebunan kelapa sawit menciptakan lapangan pekerjaan baru bagi masyarakat petani plasa dan masyarakat sekitar kebun kelapa sawit sehingga muncul peningkatan pendapatan masyarakat. Namun di sisi sosial, muncul konflik agraria antara masyarakat dengan perusahaan atas keberadaan perkebunan kelapa sawit.

Upaya penyelesaian konflik agraria antara masyarakat dengan perusahaan dilakukan diantaranya dengan musyawarah, dialog dan mediasi. Progress penyelesaian membutuhkan pihak ketiga untuk mengontrol dan menerapkan menajemen konflik yang mengarah kepada mufakat.

Adapun strategi penyelesaian konflik agraria yang sesuai untuk diterapkan dalam memperbaiki hubungan masyarakat dengan perusahaan yakni menerapkan pendekatan ekologis berupa program KKPA yang terencana dan berkelanjutan. Perusahaan membuat program pemberdayaan masyarakat melalui 
pemberian dana CSR disertai pendampingan secara terus-menerus. Sedangkan masyarakat mengelola sumber daya alam di atas lahan KKPA dengan memproduksi hasil yang sesuai kebutuhan perusahaan..

\section{DAFTAR PUSTAKA}

Badan Pusat Statistik Provinsi Riau. (2019). Provinsi Riau dalam Angka Tahun 2019.

Konsorsium Pembaharuan Agraria. (2019). Dari Aceh Sampai Papua - Urgensi Penyelesaian Konflik Agraria Struktural dan Jalan Pembaruan Agraria ke Depan. Catatan Akhir Tahun 2019.

Moleong, L. J. (2005). Metodology Penelitian Kualitatif. Remaja Risdakarya. Bandung.

Ross, Joel E. (1993). Total Quality Management: Text, Cases and Readings , London: Kogan Page Limited.

Mitchell, Bruce, B. Setiawan, Dwita H. Rahmi. (2000). Pengelolaan Sumberdaya dan Lingkungan. Gadjah Mada University Press. Yogyakarta. 